\title{
Erratum to: Career learning and development: a social constructivist model for the twenty-first century
}

\author{
Barbara Bassot
}

Published online: 23 March 2012

(C) Springer Science+Business Media B.V. 2012

\section{Erratum to: Int J Educ Vocat Guidance DOI 10.1007/s10775-012-9219-6}

Unfortunately, the acknowledgement for Fig. 1 was inadvertently missed in the original publication of the article. The acknowledgement should read as given below:

The diagram first appeared in Bassot, B. (2009). Career learning and development: A bridge to the future. In H. Reid (Ed.), Constructing the future V: Career guidance for changing contexts. Stourbridge, UK: Institute of Career Guidance. Reprinted with permission.

The online version of the original article can be found under doi:10.1007/s10775-012-9219-6.

B. Bassot $(\square)$

Canterbury Christ Church University, Canterbury, UK

e-mail: barbara.bassot@canterbury.ac.uk 